\title{
Seed-bank dynamics of native and invasive Impatiens species during a five-year field experiment under various environmental conditions
}

\author{
Hana Skálová', Lenka Moravcová', Jan Čuda', Petr Pyšek,2 \\ I Institute of Botany, The Czech Academy of Sciences, Zámek 1, CZ-252 43 Prühonice, Czech Republic 2 De- \\ partment of Ecology, Faculty of Science, Charles University, Viničná 7, CZ-128 44 Prague, Czech Republic \\ Corresponding author: Hana Skálová (hana.skalova@ibot.cas.cz)
}

Academic editor: Harald Auge | Received 25 March 2019 | Accepted 16 July 2019 | Published 26 September 2019

Citation: Skálová H, Moravcová L, Čuda J, Pyšek P (2019) Seed-bank dynamics of native and invasive Impatiens species during a five-year field experiment under various environmental conditions. NeoBiota 50: 75-95. https://doi. org/10.3897/neobiota. 50.34827

\begin{abstract}
Despite recent evidence on the important role of seed banks associated with plant invasions, and a large body of literature on invasive annual Impatiens species, little is known about the seed bank characteristics of Impatiens species. To bridge this gap, we conducted a five-year field experiment where we buried seeds of two invasive species (I. glandulifera and I. parviflora) and one native species (I. noli-tangere) across four localities in the Czech Republic, harbouring all three Impatiens species and differing in the environmental conditions. We found that the three Impatiens species differed in the characteristics of their seed banks. Both invasive species had a high seed germination rate of almost $100 \%$ in the first year after seed burial, while $<50 \%$ of seeds of the native I. noli-tangere germinated during this year. In I. parviflora all seeds germinated in the first year after seed burial and later decomposed, i.e. the species had a transient seed bank. For I. glandulifera, the most invasive species, the survival of seeds differed among localities. At the first and second localities, the seeds decomposed in the first year after seed burial; in the third locality the seeds germinated in the second year; and in the fourth one, the seeds still germinated in the fourth year. The native I. noli-tangere formed a short-term persistent seed bank across all localities. Germinating or dormant seeds were found in the third year after burial in all localities, and in one locality the seeds persisted until the fifth year. The germination and dormancy in I. noli-tangere were constrained by low minimum temperatures during winter. In addition, germination was highest at intermediate soil moisture, and the most dormant seeds were recorded in soils with intermediate nitrogen concentration. The germination of I. glandulifera was slightly limited by low soil nitrogen. However, no such effect was found in I. parviflora. We suggest that in the invasive Impatiens species seed resistance to environmental factors and high germination at least partly explain their wide distribution.
\end{abstract}

Copyright Hana Skálová et al. This is an open access article distributed under the terms of the Creative Commons Attribution License (CC BY 4.0), which permits unrestricted use, distribution, and reproduction in any medium, provided the original author and source are credited. 


\section{Keywords}

balsam, Impatiens glandulifera, Impatiens noli-tangere, Impatiens parviflora, plant invasions, seed dormancy, seed germination, soil environment

\section{Introduction}

Factors driving invasion success of alien plant species are a significant research topic in ecology and invasion biology, and this research has considerable applied relevance (Vilà et al. 2011, Pyšek et al. 2012a, Simberloff et al. 2013). Of these factors, species traits have been a research focus, and thus many studies have predicted a set of key traits associated with successful invaders, including traits related to reproduction (for a review see Pyšek and Richardson 2007, van Kleunen et al. 2010). Successful invaders are typically characterised by massive seed production (Moravcová et al. 2010, 2015) and early and/or rapid germination (Schlaepfer et al. 2010, Wilsey et al. 2015, Gioria and Pyšek 2017), which allows them to germinate and establish seedlings when competition from resident plants is low (Gioria et al. 2018).

Some studies pointed to the important role of soil seed banks in species invasiveness, as the formation of a seed bank represents a mechanism by which a species can persist in the invaded localities (Thuiller et al. 2008, Gioria et al. 2011, 2012). Persistent soil seed banks allow species to survive in the soil when conditions for germination or reproduction are unfavourable. In addition, seed banks maintain population genetic diversity, and thus improve the ability of alien species to respond to novel site conditions encountered in the introduced range by spreading the environmental risks over time (Gioria et al. 2012). The role of seed banks in population persistence has to be taken into account during eradication, because a few viable seeds in the soil may allow re-invasions (Fletcher et al. 2015, Leary et al. 2018, Moravcová et al. 2018).

The capacity to form a persistent soil seed bank was revealed as the most powerful trait explaining the large ecological amplitude of Central European species in their native range, as well as the naturalisation success of these species in North America (Pyšek et al. 2015). Successful invasive species often have larger and longer-persisting seed banks when compared to their native congeners or confamiliars (Pyke 1990, Honig et al. 1992, Van Clef and Stiles 2001) or non-invasive species (Radford and Cousens 2000, Phillips and Murray 2012). Furthermore, the timing of germination from soil seed banks is supposed to be an important factor influencing plant invasions (Gioria et al. 2018). Unfortunately, the data on seed banks of individual species are still rather scarce and often disconnected from other traits, regardless of the fact that the seed bank characteristics contribute to understanding the invasion success of plant species, especially of annuals that are strictly dependent on population recovery from seed. Studies that included seed banks characteristics as explanatory variable suggest that it 
is an important trait contributing to the invasion success of species (Pyšek et al. 2015). In addition, the seed bank characteristics should be taken into account for eradication plans, while monitoring of the eradicated sites should be longer than seed bank longevity to prevent population recovery.

As other life stages of plants, seed bank dynamics are influenced by environmental factors. Surprisingly, only a few studies have addressed this topic. The existing studies demonstrated the role of habitat (Hesse et al. 2007), water and temperature (Schafer and Kotanen 2003), precipitation (Bebawi et al. 2015), soil type (Abedi et al. 2014, Bebawi et al. 2015), soil pH (Basto et al.2015 and Pakeman et al. 2012) and soil nutrients (Moravcová et al. 2018 and Pakeman et al. 2012).

We used a group of central European annual species belonging to the genus Impatiens, i.e. the native I. noli-tangere and the invasive I. glandulifera and I. parviflora, which co-occur in the same localities and have been assessed previously for traits associated with invasiveness. The invasive I. glandulifera is characterised by rapid and high germination (Perglová et al. 2009), a high biomass throughout the species life cycle (Skálová et al. 2012, 2013), and its competitiveness (Čuda et al. 2015). The invasive $I$. parviflora invests more resources into reproduction than $I$. glandulifera or the native I. noli-tangere (Skálová et al. 2013, Minden and Gorschlüter 2016). All three species show among-population variation in germination and frost resistance reflecting conditions from localities where the seeds were collected (Skálová et al. 2011), as well as differences in seedling but not adult traits (Skálová et al. 2012, 2013). This indicates that development in the juvenile stages is crucial for these annual species to reach the single reproductive event in their life cycle (Čuda et al. 2016). One response to compensate for possible failure before reaching reproduction is to store seeds in the soil seed bank.

Seed banks are a part of the life cycle of Impatiens species that are poorly understood. Information about their seed banks is mostly based on indirect observations, for example, the occurrence of seedlings after thwarting seed production due to the removal of plants before fruiting, or it was tested in the laboratory or in an experimental garden (see Perglová et al. 2009), where ecological conditions differ from field sites. The garden experiment indicated no persistent soil seed bank in two invasive species I. parviflora and I. glandulifera, but a short-term persistent seed bank in the native $I$. noli-tangere. However, together with seed persistence the timing of germination from the seed bank could be another important factor influencing invasiveness (Gioria et al. 2018).

To improve the seed bank knowledge for Impatiens species, we established a burial experiment in which we studied germination, dormancy and seed persistence of I. glandulifera, I. noli-tangere and I. parviflora for five years in natural populations in the Czech Republic, harbouring all three Impatiens species and differing in the environmental conditions. We assessed whether seed bank dynamics and seed persistence in the field (i) differ among the invasive and native species, (ii) differ across and within individual localities, (iii) and whether they are influenced by environmental factors. 


\section{Methods}

\section{Study species}

The three Impatiens species have similar life histories and reproductive characteristics (Coombe 1956, Beerling and Perrins 1993, Hatcher 2003, Adamowski 2008). Impatiens noli-tangere L., a native species to central Europe, is recorded from 39 habitat types in the Czech Republic (Sádlo et al. 2007), mainly from damp forests, clearings and riparian habitats (Slavík 1997). Impatiens glandulifera Royle, a highly invasive species which occurs predominantly along rivers, has also colonised forest clearings and margins, wet ditches, forest roads and ruderal sites (Čuda et al. 2017). In the Czech Republic, the first record of cultivation is from 1846 and that of occurrence outside cultivation from 1896 (Slavík 1997). The species is recorded from 16 habitat types (Sádlo et al. 2007, Pyšek et al. 2012b, Pahl et al. 2013), but this number is expected to increase due to its ongoing spread. Impatiens parviflora DC., an invasive species, is characterised by broad ecological amplitude, being recorded from 45 habitat types in the Czech Republic (Sádlo et al. 2007, Pyšek et al. 2012c). In this country it was first recorded in 1844 in a botanical garden in Prague, and outside cultivation around 1870 (Slavík 1997). It often grows as a dominant species in nitrophilous herbaceous vegetation of shady mesic sites, in alluvial forests, oak-hornbeam forests, ravine forests, and spruce or Robinia pseudoacacia plantations (Pyšek et al. 2012b), and its current spread is slower, indicating limits of distribution.

The presence of Impatiens species depends on some degrees of disturbance, and thus they often occur in early-successional herbaceous communities. They coexist in some localities where the spatial pattern of the occurrence is driven by canopy closure and water availability (Čuda et al. 2014). Seeds of the species differ in the stratification demands and germination rates (Perglová et al. 2009, Skálová et al. 2011). Seeds of I. glandulifera only require a short period of cold-wet stratification after which most of them germinate, while I. parviflora requires a long period of stratification, which is followed by germination of a high percentage of seed, and I. noli-tangere has the longest stratification period but the lowest germination. Both seedling and adult plants of the three species suffer from frost damage (Coombe 1956, Beerling and Perrins 1993, Perrins et al. 1993, Hatcher 2003, Skálová et al. 2011), and this may be one of the factors limiting their spread. The temperature regime of the seed source explained differences in frost sensitivity among populations of I. glandulifera and I. parviflora, while in $I$. noli-tangere and I. parviflora the temperature influenced the time of germination (Skálová et al. 2011). In addition, populations of I. glandulifera differ in flowering phenology along latitudinal gradients (Kollmann and Bañuelos 2004). Finally, for all three species differences among populations were observed for seedling height, biomass and root/shoot ratio, with stronger differentiation in the invasive species (Skálová et al. 2012). 
Table I. Characteristics describing the four localities for burial of Impatiens seeds. The climatic profiles for each locality were taken from Tolasz (2007).

\begin{tabular}{|c|c|c|c|c|c|c|c|c|c|c|c|}
\hline 疍 & 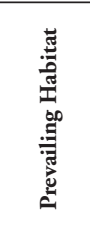 & 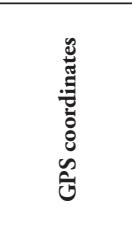 & 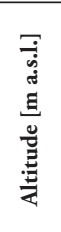 & 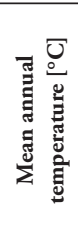 & 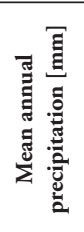 & 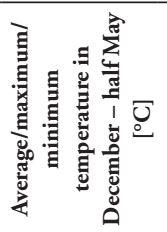 & 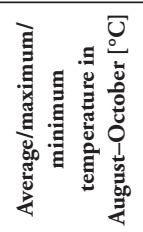 & 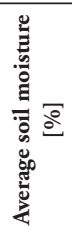 & 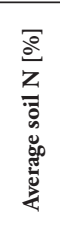 & 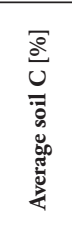 & 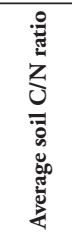 \\
\hline Čelina & $\begin{array}{l}\text { mixed } \\
\text { forest }\end{array}$ & $\begin{array}{l}49^{\circ} 43.87^{\prime} \mathrm{N} \\
14^{\circ} 20.67^{\prime} \mathrm{E}\end{array}$ & 300 & 8 & 500 & $3.7 / 16.7 /-4.0$ & $13.2 / 31.5 / 1.5$ & 49.2 & 0.31 & 3.95 & 13.06 \\
\hline Potštejn & $\begin{array}{c}\text { alluvial } \\
\text { forest }\end{array}$ & $\begin{array}{c}50^{\circ} 04.25^{\prime} \mathrm{N} \\
16^{\circ} 19.42^{\prime} \mathrm{E}\end{array}$ & 340 & 7 & 650 & $4.3 / 16.6 / 0.1$ & $13.8 / 34.0 / 0.7$ & 49.7 & 0.15 & 1.92 & 12.46 \\
\hline Třebsín & $\begin{array}{l}\text { mixed } \\
\text { forest }\end{array}$ & $\begin{array}{c}49^{\circ} 51.57^{\prime} \mathrm{N} \\
14^{\circ} 27.93^{\prime} \mathrm{E}\end{array}$ & 280 & 8 & 550 & $4.0 / 14.9 /-1.7$ & $13.0 / 33.6 / 0.5$ & 50.9 & 0.80 & 13.54 & 15.62 \\
\hline Volyně & $\begin{array}{c}\text { alluvial } \\
\text { forest }\end{array}$ & $\begin{array}{l}49^{\circ} 08.50^{\prime} \mathrm{N} \\
13^{\circ} 53.73^{\prime} \mathrm{E}\end{array}$ & 460 & 7 & 500 & $3.5 / 17.6 /-5.0$ & $13.4 / 22.5 / 0.5$ & 63.1 & 0.57 & 6.83 & 12.01 \\
\hline
\end{tabular}

\section{Seed burial experiment}

Seeds of I. noli-tangere and I. parviflora were collected in July 2008, and of I. glandulifera in August 2008. Four localities, that harboured all three Impatiens species and differed in temperature, precipitation and soil nutrients, were selected in the Czech Republic (Table 1) to investigate site-specific differences in the seed banks of the species (Čuda et al. 2014). Seeds from the same localities were used in previous experiments (Skálová et al. 2011, 2012, 2013), thus consistently including maternal effects (Roach and Wulff 1987, Galloway 2005). For each species, a mixed sample of seeds from at least 100 randomly chosen individuals across each locality was collected in the summer of 2008. In the localities Čelina, Třebsín and Volyně, at least 3,000 seeds per species were collected; in Potštejn only about 2,000 seeds of I. noli-tangere and $I$. parviflora were collected due to the low seed production. After collection, the seeds were dry stored at room temperature. Polyamide bags (fabric Norin, $6 \times 6 \mathrm{~cm}$ ) containing 50 seeds for each species were buried in late November 2008. In each locality only locally collected seeds were buried. As we found differentiation among species with I. glandulifera occurring in less shaded sites than I. noli-tangere and I. parviflora (Čuda et al. 2014), the bags were buried within the respective populations. In Čelina, Třebsín and Volyně, 54 bags for each species were buried, respectively (i.e. three replicates within each of two sites retrieved across nine time points), while in Potštejn 36 bags were buried due to the seed shortage (i.e. three replicates within each of two sites retrieved across six time points). The bags with seeds of individual species were joined to triplets (one bag per species) for each replicate, site and time point, and sewed to the end of an about $1 \mathrm{~m}$ long string; the second end of the string was used to make it easier to find the seed bags in the field and to enable their careful removal from the soil. In addition each triplet was equipped with an iron ring for proper localisation of 
the bags using a metal detector to minimise soil disturbance during excavation. Along 3-m transects the bags were horizontally placed into the upper soil layer, at a depth of $5 \mathrm{~cm}$ (Suppl. material 1: Fig. S1). The turf was carefully removed and placed back after burial of the bags. The ends of each transect were marked by wooden and iron sticks. The seeds were exhumed in the following years in late March and late May (2009-2012), and in late March 2013.

After exhumation, the bags were washed and the seeds separated as (i) germinated, (ii) decayed in the soil (i.e. this category consisted of dead non-germinated seeds) or (iii-v) supposedly viable. A seed was considered germinated if at least the tip of the radicle was visible. The supposedly viable seeds were placed in Petri dishes filled with heat-sterilised river sand which was kept wet using tap water. The dishes were placed into a growth chamber with $12 / 12$ day/night regime of $15 / 5^{\circ} \mathrm{C}$ (this corresponds to the mean early-spring temperature in the Czech Republic); seed germination was checked every second day. Germinating seeds were considered as (iii) non-dormant, while seeds that did not germinate within one month were stained with tetrazolium to further differentiate between (iv) dormant and (v) dead seeds. Species- and site-specific dynamics of the soil seed bank were described as the total numbers of germinating seeds (i+iii) and that of dormant seeds (iv).

\section{Environmental variables}

Since seed bank depletion is influenced by water and temperature, and at least partly moderated by soil microbial activity (Schafer and Kotanen 2003), we measured soil moisture and temperature within $5 \mathrm{~m}$ of the burial sites. Temperature was measured using IBTN sensors (Thermochron Generic F5ROHS DS1921G-F5\#) at the two sites per each of the four localities from December 2008 until the end of April 2009. The sensors were placed at the soil surface, covered with a thin layer of litter, and temperatures were recorded every 2 hours. Due to technical problems, we could not obtain the data from one temperature sensor in Potštejn. During both exhumations in 2009, we measured soil moisture using a moisture meter $\mathrm{HH} 2$ device with probe Theta Probe ML29 (Delta-T Devices, UK). The measurement was done at six places within $3 \mathrm{~m}$ around the burial sites. These values were averaged for each site.

Seed longevity and seed bank abundance are influenced by soil conditions ( $\mathrm{Pa}-$ keman et al. 2012, Abedi et al. 2014, Basto et al. 2015, Moravcová et al. 2018), and thus we included soil data from neighbouring plots collected during previous studies (Čuda et al. 2014). Total $\mathrm{C}$ and $\mathrm{N}$ were measured in soil samples taken close to the plots (i.e. up to $1 \mathrm{~m}$ ) at each locality in 2008 and 2009, using Carlo Erba NC 2500 analyser. For the analyses, we included data for 1-3 plots that were up to $30 \mathrm{~m}$ from each of the burial sites, as well as those with similar environments. The soil samples were taken from the upper horizon $(0-5 \mathrm{~cm})$, which corresponds to the burial depth. 


\section{Data analysis}

The depletion pattern of the soil seed-bank of Impatiens species was tested using generalised linear mixed-effect models with binomial error structure and logit link function. The proportion of germinating and dormant seeds in each bag were used as the response variables. The predictor variables (i.e. Impatiens species, year and month of exhumation, locality and site, and two-way interactions of these variables) were fixed effects within the models. Plot ID was used as a random factor to account for repeated measurements within the same plot over time (i.e. temporal pseudoreplications). The number of seeds in each bag $(\mathrm{n}=50)$ was set as the "weights" argument within the glmer function and represented the number of trials used to generate each proportion (i.e. numbers of germinating or dormant seeds in each of the 50 bags). The year was treated as a continuous variable because we expected a gradual decrease in seed viability with time. We also examined the effect of environmental factors on Impatiens seed germination and dormancy from the first seed burial until the first exhumation in March 2009.

Due to the strong correlation between three measures of soil temperature (minimum, maximum and mean, Suppl. material 2: Fig. S2) we decided to use only minimum temperature that is most important for seed germination and dormancy, because frost may kill germinating seeds (Čuda et al. 2015). Similarly, soil carbon and nitrogen were highly correlated, and the latter variable was selected. Thus, we tested the effect of winter minimum temperature in the upper soil layer, soil nitrogen and soil moisture on seed germination and dormancy. Furthermore, since environmental data was only available at the site level, we used the means for seed germination and dormancy as response variables (i.e. average of three bags with 50 seeds per site).

Models were built separately for each species, and the square function of these variables was included to account for possible non-linear relationships. Locality was set as a random factor to reflect similarity within each locality (i.e. spatial pseudoreplication). Finally, we fitted separate models for each significant environmental variable, its square function and species (five models in total) to visualise the individual speciesenvironment relationships. Maximal models were simplified by backward elimination of non-significant terms and retention of significant ones. The deletion of terms was validated step-by-step by comparing the significances between the original and the simplified models (Crawley 2013). The differences within significant terms were posthoc tested by Tukey HSD pairwise comparison of estimated marginal means (Lenth 2018). Apart from R base packages, we used lme4 for fitting generalised mixed-effect models by glmer function (Bates et al. 2015), and emmeans for subsequent multiple comparisons among significant terms (Lenth 2018). Package effects was used to calculate the effects of significant environmental variables in the models for germination and dormancy. Graphs were plotted using the packages $d p l y r$ (Wickham et al. 2018) and ggplot2 (Wickham 2016). All computations were done in programme R 3.5.1 (R Core Team 2018). 


\section{Results}

\section{Seed germination}

Germination was highest in the first spring after burial of the seed bags (i.e. March 2009) and differed significantly among the Impatiens species (Fig. 1, Table 2, Suppl. material 4: Table S1). During this time, germination was much higher for the invasive $I$. glandulifera and I. parviflora, with almost all seeds germinating (95\%), compared to the native $I$. noli-tangere, where less than half of the seeds germinated (42\%). Germination
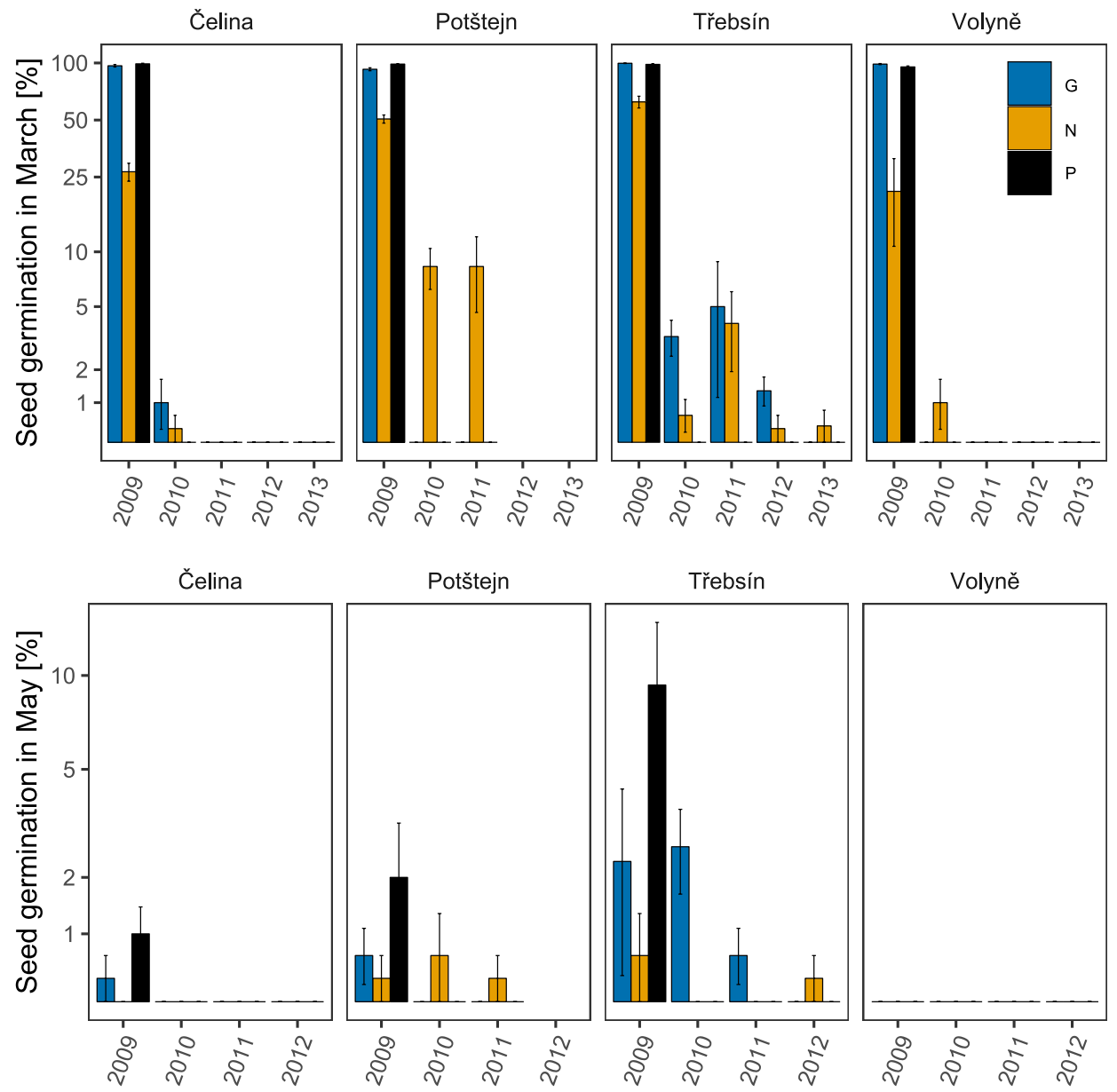

Figure I. Proportions of germinated seeds in three Impatiens species across four localities over five years in March (A) and May (B). The bars depict the average for particular combinations; vertical lines represent the standard error of the mean and horizontal lines denote zero germination. Blue bars depict I. glandulifera $(\mathrm{G})$, yellow I. noli-tangere $(\mathrm{N})$ and those in black $I$. parviflora $(\mathrm{P})$. Each bar is based on $\mathrm{n}=6$ bags comprising 50 seeds per bag (six bars is based on $n=4-5$ due to lost samples). Note that response variable and error bars are displayed in a logarithmic scale. Seeds were only buried for three years at Potštejn due to seed shortage. 
Table 2. The effect of selected factors and their two-way interactions on Impatiens germination. Summary of generalised linear mixed-effect model, where minimal adequate model is presented and significant values $(\mathrm{p}<0.05)$ are in bold. Degrees of freedom, statistics of likelihood-ratio tests and $\mathrm{p}$ values are shown.

\begin{tabular}{lccc}
\hline Factor & df & $\chi^{\mathbf{2}}$ & $\mathbf{p}$ \\
\hline Species & 2 & 37.39 & $<\mathbf{0 . 0 0 1}$ \\
Year & 1 & 746.28 & $<\mathbf{0 . 0 0 1}$ \\
Month & 1 & 730.31 & $<\mathbf{0 . 0 0 1}$ \\
Locality & 3 & 21.81 & $<\mathbf{0 . 0 0 1}$ \\
Site & 1 & 1.05 & 0.161 \\
Species $\times$ year & 2 & 173.19 & $<\mathbf{0 . 0 0 1}$ \\
Species $\times$ locality & 6 & 7.16 & $<\mathbf{0 . 0 0 1}$ \\
Year $\times$ month & 1 & 200.02 & $<\mathbf{0 . 0 0 1}$ \\
Year $\times$ locality & 3 & 15.40 & $<\mathbf{0 . 0 0 1}$ \\
Year $\times$ site & 1 & 3.81 & $\mathbf{0 . 0 1 2}$ \\
Month $\times$ locality & 3 & 5.75 & $\mathbf{0 . 0 0 2}$ \\
Month $\times$ site & 1 & 6.81 & $\mathbf{0 . 0 4 8}$ \\
Locality $\times$ site & 3 & 8.02 & $<\mathbf{0 . 0 0 1}$ \\
\hline
\end{tabular}

ability dropped rapidly during May of the same year, and decreased further in the following years. Importantly, we found no germination of I. parviflora seeds following the first year of burial. For the other species, germination was higher in March than in May of the following years. The difference between these two months was most obvious in the first year, but still remained significant over time $(\mathrm{P}<0.001, \mathrm{~F}=29.5)$.

Germination also differed across localities (Fig. 1, Table 2). In Třebsín, a high percentage of seeds germinated and this was true for the first as well as the subsequent years. All species maintained their germinability for the longest duration at this locality. Seeds of I. parviflora were germinable for one year, I. glandulifera for four years, and the native I. noli-tangere for all five years. Importantly, I. glandulifera was germinable for more than one year only at this locality, and to a small extent in Čelina in the second year, while I. noli-tangere was germinable in all four localities, while the germination rate was very low in Čelina and Volyně where the seeds were germinable only for two years. Lastly, we found no significant effect of site, i.e. regardless of whether the seeds were buried under I. glandulifera stands or mixed stands of I. noli-tangere and I. parviflora.

\section{Seed dormancy}

The results for dormancy corresponded well with those for germination. We found significant effects of species, year of exhumation, and locality, as well as non-significant effects of site (Table 3). Unlike seed germination, there was no difference between the months of seed exhumation (i.e. March and May). We did not record any dormant seeds for I. parviflora, while we found dormant seeds for up to four years in I. glandulifera and I. noli-tangere (Fig. 2, Suppl. material 4: Table S1).

Dormancy decreased with time, however the decline between the first and second year was not as rapid as for germination. The sites varied considerably in dormancy and the pattern was similar for the results of germination after the first year. The most dor- 
Table 3. The effect of selected factors and their two-way interactions on Impatiens seed dormancy. Summary of generalised linear mixed-effect model, where minimal adequate model is presented, significant values are in bold.

\begin{tabular}{lccc}
\hline Factor & df & $\chi^{\mathbf{2}}$ & $\mathbf{p}$ \\
\hline Species & 2 & 50.18 & $<\mathbf{0 . 0 0 1}$ \\
Year & 1 & 84.40 & $<\mathbf{0 . 0 0 1}$ \\
Month & 1 & 1.13 & 0.296 \\
Locality & 3 & 44.09 & $<\mathbf{0 . 0 0 1}$ \\
Site & 1 & 0.50 & 0.471 \\
Species $\times$ month & 2 & 4.49 & $\mathbf{0 . 0 1 0}$ \\
Species $\times$ locality & 6 & 4.76 & $<\mathbf{0 . 0 0 1}$ \\
Year $\times$ site & 1 & 5.08 & $\mathbf{0 . 0 2 4}$ \\
\hline
\end{tabular}
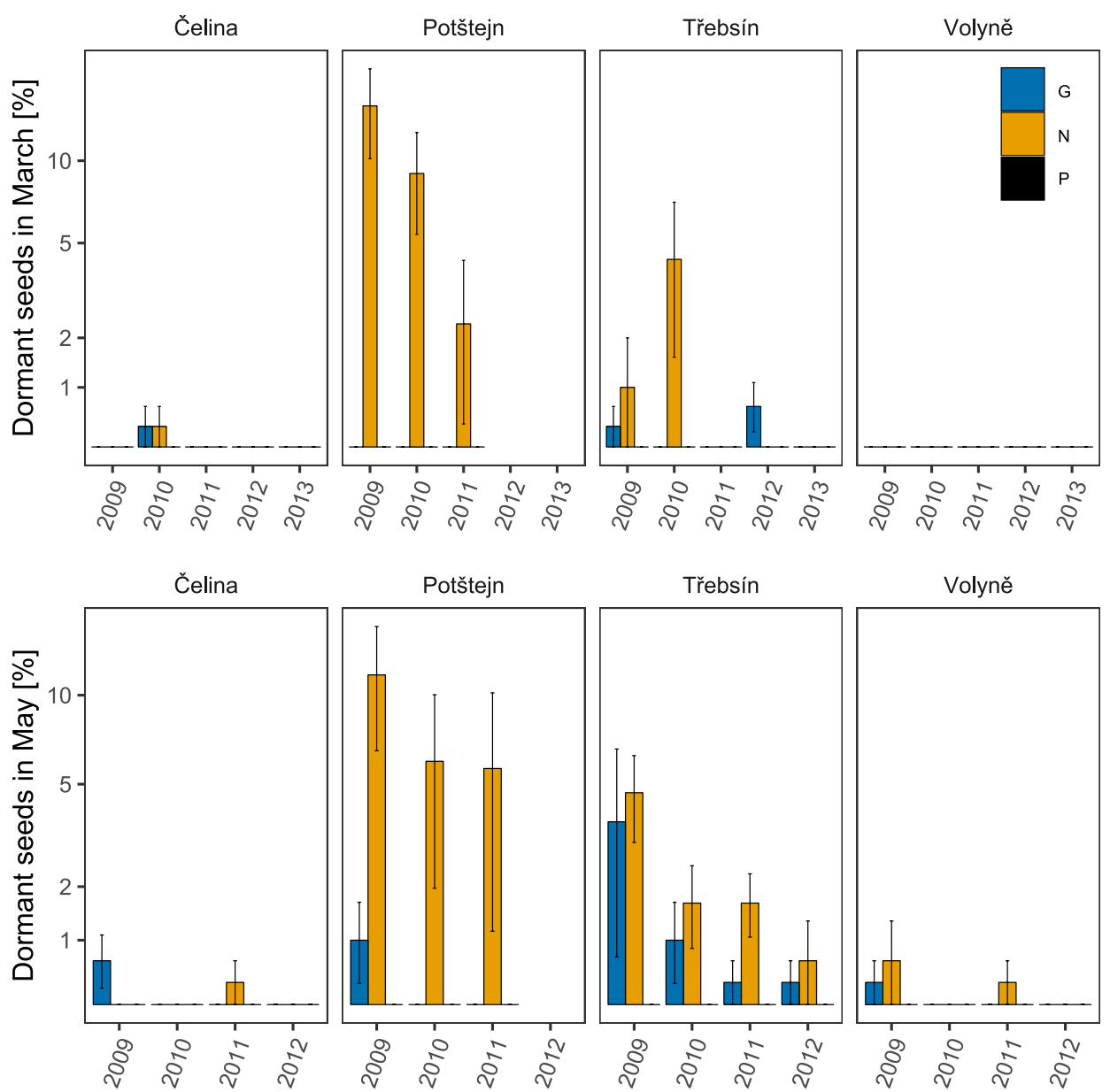

Figure 2. Proportions of dormant seeds in three Impatiens species across four localities over five years in March (A) and May (B). For details see Figure 1. 
mant seeds over the four-year period for I. glandulifera were found in Truebsín, while, in the other localities, dormant seeds were only found up to the second year. Impatiens noli-tangere had the highest dormancy in Potštejn followed by Třebsín.

\section{Environmental effects on seed banks}

The effect of environmental factors on seed germination and dormancy in 2009 was most pronounced for the native I. noli-tangere (Fig. 3, Table 4). Seed germination and dormancy across sites increased with growing winter minimum temperature (see Suppl. material 3: Fig. S3 for detailed temperature course across localities). Seed germination exhibited a unimodal relationship with soil moisture, with the highest percentages recorded in moderately wet sites (i.e. soil moisture of 60\%). The same relationship was recorded between seed dormancy and soil nitrogen concentration, with dormancy being low under intermediate nitrogen levels. In I. glandulifera, there was a slight positive effect of soil nutrient content on seed germination. However, we did not find any significant effect of environmental conditions on germination in $I$. parviflora.
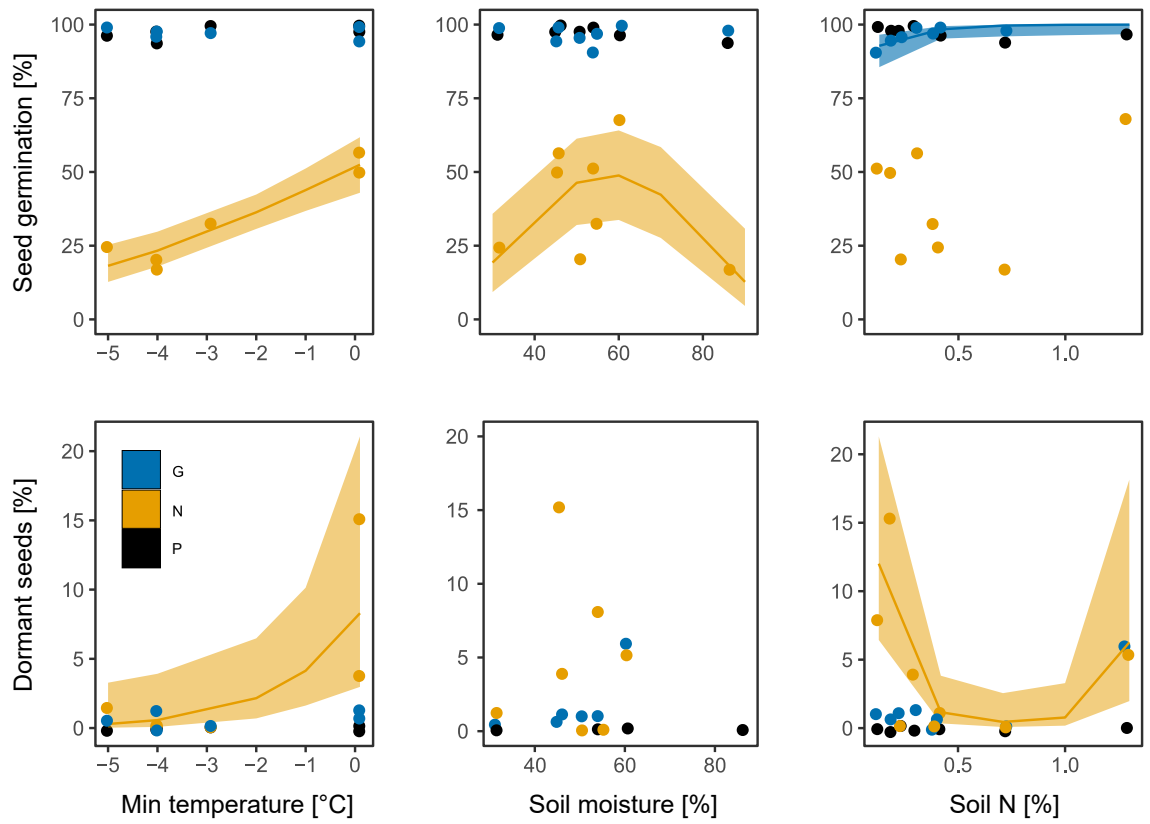

Figure 3. The effects of winter minimum temperature, soil moisture, and soil nitrogen concentration on seed germination in March 2009 and dormancy in May 2009. Blue circles depict I. glandulifera (G), yellow I. noli-tangere $(\mathrm{N})$ and those in black I. parviflora $(\mathrm{P})$. Lines in the same colours show a significant relationship fitted with generalised linear mixed effect models, shading indicates $95 \%$ confidence intervals (yellow in I. noli-tangere and blue in I. glandulifera). Models for each species are based on 8 replicates (i.e. 2 sites at each of the 4 localities). The mean of three replicates per locality and site were used for seed germination and dormancy. 
Table 4. The effect of environmental factors and their square functions on Impatiens germination and dormancy for March 2009. The minimal models for each species are presented, terms that were excluded within the model simplification are marked with -, and significant values are in bold. Dormancy of I. parviflora seeds were not tested (n.t.) because there were no dormant seeds across all plots.

\begin{tabular}{llccccc}
\hline Species & Factor & $\mathrm{df}$ & \multicolumn{2}{c}{ Germination March } & \multicolumn{2}{c}{ Dormancy May } \\
\cline { 4 - 7 } & & & $\chi^{2}$ & $\mathrm{p}$ & $\chi^{2}$ & $\mathrm{p}$ \\
\hline I. glandulifera & winter minimum temperature & 1 & 0.49 & 0.484 & 0.17 & 0.684 \\
& soil moisture & 1 & 0.48 & 0.491 & 0.22 & 0.638 \\
& soil N & 1 & 4.30 & $\mathbf{0 . 0 3 8}$ & 2.07 & 0.150 \\
I. parviflora & winter minimum temperature & 1 & 1.83 & 0.176 & n.t. & n.t. \\
& soil moisture & 1 & 1.59 & 0.208 & n.t. & n.t. \\
& soil N & 1 & 2.29 & 0.129 & n.t. & n.t. \\
I. noli-tangere & winter minimum temperature & 1 & 25.12 & $<\mathbf{0 . 0 0 1}$ & 5.94 & $\mathbf{0 . 0 1 5}$ \\
& soil moisture & 1 & 15.70 & $<\mathbf{0 . 0 0 1}$ & 1.07 & 0.300 \\
& soil moisture & 1 & 16.18 & $<\mathbf{0 . 0 0 1}$ & - & - \\
& soil N & 1 & 1.53 & 0.215 & 9.54 & $\mathbf{0 . 0 0 2}$ \\
& soil $\mathrm{N}^{2}$ & 1 & - & - & 8.99 & $\mathbf{0 . 0 0 3}$ \\
\hline
\end{tabular}

\section{Discussion}

\section{Species- and site-specific germination}

We found significant differences in seed germination between the native and invasive Impatiens species, as well as across the four localities. The high germination rate for the invasive species is in agreement with findings from a garden experiment (Perglová et al. 2009). On the other hand, the germination of the native I. noli-tangere was considerably higher in the four localities compared to the common garden $(8 \%$; Perglová et al. 2009). This indicates the key role of local conditions, and it also highlights the limitations of garden experiments. Our results also support previous findings which suggest that high germination success of alien invasive species, compared to their native congeners, promotes invasiveness (Pyšek and Richardson 2007).

\section{Seed-bank dynamics and invasive species management}

While seed persistence is suggested to be associated with invasiveness (e.g. Pyke 1990, Radford and Cousens 2000, van Clef and Stiles 2001, Gioria et al. 2012, Pyšek et al. 2015), we found that the most persistent seed bank was associated with the native I. noli-tangere. In our study system, this might indicate that early massive germination, that occurred shortly after seed burial (i.e. during early spring), of the two invasive Impatiens species may be another factor contributing to their invasion success, more than seed persistence (cf. Gioria et al. 2018), provided that the timing coincides with favourable environmental conditions.

In I. parviflora we recorded germination only in the first year after seed burial, while no dormant seeds persisted throughout the experiment. Consequently, due to 
the absence of seeds after spring germination, as well as a modest root system (Slavík 1997), mechanical eradication could be an effective treatment for this species. Despite its weak impact on native vegetation (Hejda 2012, Diekmann et al. 2016, Florianová and Münzbergová 2017) and general recommendation for tolerance (Pergl et al. 2016), eradication is being applied in some areas, typically in communities with greater conservation values, such as thermophilous oak forests or steppes on rocks (Pyšek et al. 2012b, Florianová and Münzbergová 2017). These actions have been reported from Poland (Adamowski and Keczynski 1999), Hungary (Csontos 1986) and more recently also from protected areas of the Czech Republic (Pěknicová 2008). Transient soil seed banks (sensu Thompson et al. 1997), high sensitivity to frost (Skálová et al. 2011) and low competitive ability (Čuda et al. 2015) together represent a rather sensitive stage in population development that is probably partly compensated by a wide ecological amplitude (Pyšek et al. 2012c), high investment into reproduction (Skálová et al. 2013), high seed production compared to the native congener (Daumann 1967), and properly timed and synchronised germination (Skálová et al. 2011, Perglová et al. 2009).

The highly invasive $I$. glandulifera forms short-term persistent soil seed banks (sensu Thompson et al.1997) at suitable localities. We found germinating and dormant seeds of I. glandulifera in the second year after seed burial at two of the four localities, while in Třebsín, germinating and dormant seeds were found still after four years. We are not aware of any data on the seed bank of I. glandulifera reported from the field conditions prior to our study. Until now, only indirect evidence was used to infer the seed-bank dynamics of this species, for example, the occurrence of seedlings after the removal of plants before fruiting. Beerling and Perrins (1993) observed seedlings for up to 18 months after plant removal; this indicates a two-year persistence of seed viability in this species. Even longer persistent seed banks were indicated by an eradication study with plants being found after four years (Saegesser et al. 2016). Our field experiment supports these indirect observations and also reveals that I. glandulifera seeds are able to survive in the soil much longer than previously thought. On the other hand, a four-year soil seed bank is the maximum survival period that was reached by a small proportion of seeds at one locality. Although the proportion of germinating seeds was very low following the first year of seed burial, the absolute number of seeds should be rather high due to abundant seed production (Daumann 1967, Beerling and Perrins 1993), a pattern similar to that found in Heracleum mantegazzianum (Moravcová et al. 2018). This suggests that in I. glandulifera the seed bank allows population recovery after disturbance. This includes damage to young plants by spring frost, which is highly probable due to early germination in that species (Perglová et al. 2009), and considerable frost sensitivity of the seedlings (Skálová et al. 2011). In addition, the seed bank must be taken into account during eradication actions, and sites should be monitored for at least four years following any control treatment. Nevertheless, systematic eradication has the potential to be very effective in small areas (Saegesser et al. 2016).

The native $I$. noli-tangere was characterised by low seed germination in the first year, but a higher proportion of germinating and dormant seeds in the following years 
compared to its invasive congeners. This strategy will likely lead to better population persistence and recovering ability, which could, however, be limited by lower seed production (Daumann 1967). In all localities, the germinating seeds were found in the second year after burial and in one site even in the fifth year. Dormant seeds were found in all localities until the third year and in one locality in the fourth year. Thus, this study revealed that the native I. noli-tangere forms short-term persistent soil seed banks (sensu Thompson et al. 1997). Despite limited data on the comparison of seed banks of native and invasive species, similar trends, i.e. lower germination in the first year but longer soil seed-bank persistence of native species compared with non-native congeners, were observed by van Clef and Stiles (2001).

\section{Soil environment and seed-bank persistence}

The seeds of the native $I$. noli-tangere were most responsive to the soil environmental factors. For I. glandulifera, the effect was low and for I. parviflora we did not detect any effect. The significant effect of environmental conditions confirms that not only species-specific attributes, but also environmental factors, determine seed longevity in the soil (Abedi et al. 2014, Long et al. 2015). This holds true for the native and partly also for the two invasive species. Sub-zero temperatures strongly decreased seed germination and dormancy of I. noli-tangere, while no such effect was detected for the invasive species. This contradicts the results of an earlier study that found the invasive species to be more sensitive to frost (Skálová et al. 2011). Seeds of I. noli-tangere germinated better under intermediate soil moisture. This may be explained by increased fungal activity (Schafer and Kotanen 2003, 2004) and also anoxic conditions in very wet soils which disrupt metabolic processes and thus cause high seed mortality (Bekker et al. 1998). On the other hand, the low germination rate may be due to the negative response of this species to low soil moisture (Skálová et al. 2013). Seed germination of $I$. glandulifera was greater at sites with high soil nitrogen concentration. These field results are in accordance with previous laboratory experiments by Andrews et al. (2009) who observed a substantial increase in seed germination of I. glandulifera under increased nitrate availability. However, we cannot exclude the positive effect due to a higher seed mass that was observed under high soil nitrogen concentration for I. parviflora (Acharya et al. 2017), and a positive correlation between seed mass and germination capacity.

The absence of environmental effects may explain the wide ecological amplitude of I. parviflora that has been recorded from 45 of 88 habitat types in the Czech Republic (Pyšek et al. 2012c). The low effects of environmental factors together with a high performance under various conditions (Skálová et al. 2012, 2013), will likely facilitate the further spread of I. glandulifera into more habitat types (currently reported in 16 habitats); small populations were recently recorded outside traditional riverine habitats of this species (Čuda et al. 2017). The wide environmental tolerance of the two alien Impatiens species probably facilitates their invasion success. 


\section{Acknowledgements}

Our thanks are due to Vendula Havlíčková, Šárka Dvořácková, Zuzana Sixtová, and Michal Pyšek for technical assistance. We are grateful to Desika Moodley for the language revision of the final text. Our thanks are also due to the editors and reviewers, especially to Johannes Kollmann, who provided us with valuable suggestions that improved the manuscript. The study was supported by project grants GAČR 17-10280S, GAČR 19-20405S, long-term research development project RVO 67985939 (The Czech Academy of Sciences). PP was supported by EXPRO grant no. 19-28807X (Czech Science Foundation).

\section{References}

Abedi M, Bartelheimer M, Poschlod P (2014) Effects of substrate type, moisture and its interactions on soil seed survival of three Rumex species. Plant and Soil 374: 485-495. https:// doi.org/10.1007/s11104-013-1903-x

Acharya KP, De Frenne P, Brunet J, Chabrerie O, Cousins SAO, Diekmann M, Hermy M, Kolb A, Lemke I, Plue J, Verheyen K, Graae BJ (2017) Latitudinal variation of life-history traits of an exotic and a native Impatiens species in Europe. Acta Oecologica 81: 40-47. https://doi.org/10.1016/j.actao.2017.05.002

Adamowski W (2008) Balsams on the offensive: the role of planting in the invasion of Impatiens species. In: Tokarska-Guzik B, Brock JH, Brundu G, Child L, Daehler CC, Pyšek P (Eds) Plant Invasions: Human Perception, Ecological Impacts and Management. Backhuys Publishers, Leiden, 57-70.

Adamowski W, Keczynski A (1999) Success of early eradication: the case of Impatens parviflora in Bialowieża National Perk (NE Poland). In: Brundu G, Brock J, Camarda I, Child L, Wade M (Eds) Proceedings of the $5^{\text {th }}$ International Conference on the Ecology of Invasive Alien Plants). Backhuys Publishers, La Maddalena, 3-5.

Andrews M, Maule, HG, Hodge S, Cherrill A, Raven A (2009) Seed dormancy, nitrogen nutrition and shade acclimation of Impatiens glandulifera: implications for successful invasion of deciduous woodland, Plant Ecology and Diversity 2: 145-153. https://doi. org/10.1080/17550870903186256

Basto S, Thompson K, Rees M (2015) The effect of soil pH on persistence of seed of grassland species. Plant Ecology 216: 1163-1175. https://doi.org/10.1007/s11258-015-0499-z

Bates D, Mächler M, Bolker BM, Walker SC (2015) Fitting linear mixed-effects models using lme4. Journal of Statistical Software 67: 1-48. https://doi.org/10.18637/jss.v067.i01

Bebawi FF, Campbell SD, Mayer RJ (2015) Seed bank longevity and age to reproductive maturity of Calotropis procera (Aiton) WT Aiton in the dry tropics of northern Queensland. Rangeland Journal 37: 239-247. https://doi.org/10.1071/RJ14130

Beerling DJ, Perrins DM (1993) Biological Flora of British Isles. Impatiens glandulifera Royle (Impatiens Roylei Walp.). Journal of Ecology 81: 367-381. https://doi.org/10.2307/2261507 
Bekker RM, Oomes MJM, Bakker JP (1998) The impact of groundwater level on soil seed bank survival. Seed Science Research 8: 399-404. https://doi.org/10.1017/S0960258500004323

Coombe DE (1956) Biological Flora of British Isles. Impatiens parviflora DC. Journal of Ecology 44: 701-714. https://doi.org/10.2307/2256857

Crawley MJ (2013) The R Book-Second Edition. Wiley. https://doi.org/10.1007/ s007690000247

Csontos P (1986) Dispersal and establishment of Impatens parviflora, an introduced plant in a hardwood forest. Abstracta Botanica 10: 341-348.

Čuda J, Skálová H, Janovský Z, Pyšek P (2014) Habitat requirements, short-term population dynamics and coexistence of native and invasive Impatiens species: a field study. Biological Invasions 16: 177-190. https://doi.org/10.1007/s10530-013-0512-1

Čuda J, Skálová H, Janovský Z, Pyšek P (2015) Competition among native and invasive Impatiens species: the roles of environmental factors, population density and life stage. AoB Plants 7: plv033. https://doi.org/10.1093/aobpla/plv033

Čuda J, Skálová H, Janovský Z, Pyšek P (2016) Juvenile biological traits of Impatiens species are more strongly associated with naturalization in temperate climate than their adult traits. Perspectives in Plant Ecology, Evolution and Systematics 20: 1-10. https://doi. org/10.1016/j.ppees.2016.02.007

Čuda J, Rumlerová Z, Brůna J, Skálová H, Pyšek P (2017) Floods affect the abundance of invasive Impatiens glandulifera and its spread from river corridors? Diversity and Distributions 23: 342-354. https://doi.org/10.1111/ddi.12524

Daumann E (1967) Zur Bestäubungs- und Verbreitungsökologie dreier Impatiens-Arten. Preslia 39: 43-58.

Diekmann M, Effertz H, Baranowski M, Dupre C (2016) Weak effects on plant diversity of two invasive Impatiens species. Plant Ecology 217: 1503-1514. https://doi.org/10.1007/ s11258-016-0663-0

Fletcher CS, Westcott DA, Murphy HT, Grice AC, Clarkson JR (2015) Managing breaches of containment and eradication of invasive plant populations. Journal of Applied Ecology 52: 59-68. https://doi.org/10.1111/1365-2664.12361

Florianová A, Münzbergová Z (2017) Invasive Impatiens parviflora has negative impact on native vegetation in oak-hornbeam forests. Flora 226: 10-16. https://doi.org/10.1016/j. flora.2016.11.006

Galloway LF (2005) Maternal effects provide phenotypic adaptation to local environmental conditions. New Phytologist 166: 93-99. https://doi.org/10.1111/j.1469-8137.2004.01314.x

Geng YP, Pan XY, Xu CY (2007) Phenotypic plasticity rather than locally adapted ecotypes allows the invasive alligator weed to colonize a wide range of habitats. Biological Invasions 9: 245-256. https://doi.org/10.1007/s10530-006-9029-1

Gioria M, Pyšek P (2017) Early bird catches the worm: germination as a critical step in plant invasion. Biological Invasions 19: 1055-1080. https://doi.org/10.1007/s10530-016-1349-1

Gioria M, Dieterich B, Osborne BA (2011) Battle of the giants: primary and secondary invasions by large herbaceous species. Biology and Environment 111: 177-193. https://doi. org/10.3318/BIOE.2011.14 
Gioria M, Pyšek P, Moravcová L (2012) Soil seed banks in plant invasions: promoting species invasiveness and long-term impact on plant community dynamics. Preslia 84: 327-350.

Gioria M, Pyšek P, Osborne BA (2018) Timing is everything: does early and late germination favor invasions by herbaceous alien plants? Journal of Plant Ecology 11: 4-16. https://doi. org/10.1093/jpe/rtw105

Hatcher PE (2003) Biological Flora of British Isles. Impatiens noli-tangere L. Jornal of Ecology 91: 147-167. https://doi.org/10.1046/j.1365-2745.2003.00741.x

Hejda M (2012) What is the impact of Impatiens parviflora on diversity and composition of herbal layer communities of temperate forests? PLOS One 7: e39571. https://doi. org/10.1371/journal.pone.0039571

Hesse E, Rees M, Mueller-Schaerer H (2007) Seed bank persistence of clonal weeds in contrasting habitats: implications for control. Plant Ecology 190: 233-243. https://doi. org/10.1007/s1 1258-006-9203-7

Honig MA, Cowling RM, Richardson DM (1992) The invasive potential of Australian banksias in South African fynbos: a comparison of the reproductive potential of Banksia ericifolia and Leucadendron laureolum. Australian Journal of Ecology 17: 305-314. https://doi. org/10.1111/j.1442-9993.1992.tb00812.x

Kollmann J, Bańuelos MJ (2004) Latitudinal trends in growth and phenology of the invasive alien plant Impatiens glandulifera (Balsaminaceae). Diversity and Distributions 10: 377385. https://doi.org/10.1111/j.1366-9516.2004.00126.x

Leary J, Mahnken B, Wada C, Burnett K (2018) Interpreting life-history traits of miconia (Miconia calvescens) through management over space and time in the east Maui watershed, Hawaii (USA) Invasive Plant Science and Management 11: 191-200. https://doi. org/10.1017/inp.2018.26

Lenth R (2018) Emmeans: Estimated marginal means, aka least-square means. R package version 1.2.1. https://CRAN.R-project.org/package=emmeans

Long RL, Gorecki MJ, Renton M, Scott JK, Colville L, Goggin DE, Commander LE, Westcott DA, Cherry H, Finch-Savage EF (2015) The ecophysiology of seed persistence: mechanistic view of the journey to germination or demise. Biological Reviews 90: 31-59. https:// doi.org/10.1111/brv. 12095

Minden V, Gorschlüter J (2016) Comparison of native and non-native Impatiens species across experimental light and nutrient gradients. Plant Ecology and Evolution 149: 59-72. https://doi.org/10.5091/plecevo.2016.1118

Moravcová L, Pyšek P, Jarošík V, Pergl J (2015) Getting the right traits: reproductive and dispersal characteristics predict the invasiveness of herbaceous plant species. PLOS One 10: e0123634. https://doi.org/10.1371/journal.pone.0123634

Moravcová L, Pyšek P, Jarošík V, Havlíčková V, Zákravský P (2010) Reproductive characteristics of neophytes in the Czech Republic: traits of invasive and non-invasive species. Preslia 82: $365-390$.

Moravcová L, Pyšek P, Krinke L, Müllerová J, Perglová I, Pergl J (2018) Long-term survival in soil of seed of the invasive herbaceous plant Heracleum mantegazzianum. Preslia 90: 225-234. https://doi.org/10.23855/preslia.2018.225 
Pakeman RJ, Small JL, Torvell L (2012) Edaphic factors influence the longevity of seeds in the soil. Plant Ecology 213: 57-65. https://doi.org/10.1007/s11258-011-0006-0

Pahl AT, Kollmann J, Mayer A, Haider S (2013) No evidence for local adaptation in an invasive alien plant: field and greenhouse experiments tracing a colonization sequence. Annals of Botany 112: 1921-1930. https://doi.org/10.1093/aob/mct246

Pěknicová J (2008) Netýkavka malokvětá v porostech bučin v CHKO Kokořínsko (Ústí nad Labem): http://www.npcs.cz/netykavka-malokveta-pod-pravcickou-branou

Pergl J, Sádlo J, Petrusek A, Laštůvka Z, Musil J, Perglová I, Šanda R, Šefrová H, Šíma J, Vohralík V, Pyšek P (2016) Black, grey and watch lists of alien species in the Czech Republic based on environmental impacts and management strategy. NeoBiota 28: 1-37. https:// doi.org/10.3897/neobiota.28.4824

Perglová I, Pergl J, Skálová H, Moravcová L, Jarošík V, Pyšek P (2009) Differences in germination and seedling establishment of alien and native Impatiens species. Preslia 81: 357-375.

Perrins J, Fitter A, Williamson M (1993) Population biology and rates of invasion of three introduced Impatiens species in the British Isles. Journal of Biogeography 20: 33-44. https:// doi.org/10.2307/2845737

Phillips ML, Murray BR (2012) Invasiveness in exotic plant species is linked to high seed survival in the soil. Evolutionary Ecology Research 14: 83-94.

Pyke DA (1990) Comparative demography of co-occurring introduced and native tussock grasses: persistence and potential expansion. Oecologia 82: 537-543. https://doi.org/10.1007/ BF00319798

Pyšek P, Richardson DM (2007) Traits associated with invasiveness in alien plants: Where do we stand? In: Nentwig W (Ed.) Biol invasions, Ecological Studies 193, Springer-Verlag, Berlin/Heidelberg, 97-126. https://doi.org/10.1007/978-3-540-36920-2_7

Pyšek P, Chytrý M, Pergl J, Sádlo J, Wild J (2012b) Plant invasions in the Czech Republic: current state, introduction dynamics, invasive species and invaded habitats. Preslia 84: 575-629.

Pyšek P, Jarošík V, Hulme PE, Pergl J, Hejda M, Schaffner U, Vilà M (2012a) A global assessment of invasive plant impacts on resident species, communities and ecosystems: the interaction of impact measures, invading species' traits and environment. Global Change Biology 18: 1725-1737. https://doi.org/10.1111/j.1365-2486.2011.02636.x

Pyšek P, Manceur AM, Alba C, McGregor KF, Pergl J, Štajerová K, Chytrý M, Danihelka J, Kartesz J, Klimešová J, Lučanová M (2015) Naturalization of central European plants in North America: species traits, habitats, propagule pressure, residence time. Ecology 96: 762-774. https://doi.org/10.1890/14-1005.1

Pyšek P, Danihelka J, Sádlo J, Chrtek Jr J, Chytrý M, Jarošík V, Kaplan Z, Krahulec F, Moravcová L, Pergl J, Štajerová K, Tichý L (2012c) Catalogue of alien plants of the Czech Republic $\left(2^{\text {nd }} \mathrm{edn}\right)$ : checklist update, taxonomic diversity and invasion patterns. Preslia 84: $155-255$.

R Core Team (2018) R: A language and environment for statistical computing. R Foundation for Statistical Computing, Vienna. https://www.R-project.org/

Radford IJ, Cousens RD (2000) Invasiveness and comparative life history traits of exotic and indigenous Senecio species in Australia. Oecologia 125: 531-542. https://doi.org/10.1007/ s004420000474 
Rejmánek M, Richardson DM, Pyšek P (2005) Plant invasions and invasibility of plant communities. In: Van der Maarel E (Ed.) Vegetation Ecology. Blackwell, Oxford, 332-355.

Roach DA, Wulff RD (1987) Maternal effects in plants. Annual Review of Ecology and Systematics 18: 209-235. https://doi.org/10.1146/annurev.es.18.110187.001233

Sádlo J, Chytrý M, Pyšek P (2007) Regional species pools of vascular plants in habitats of the Czech Republic. Preslia 79: 303-321.

Saegesser J, Fischer D, Fischer K (2016) Long-term control of Impatiens glandulifera in a Swiss Forest: does zero-tolerance pay off? Biological invasions: interactions with environmental change. In: Ries C, Krippel Y (Eds) Book of abstracts. Neobiota $2016-9^{\text {th }}$ International Conference on Biological Invasions. Fondation fauneflore, Vianden, 69.

Schlaepfer DR, Glättli M, Fischer M, van Kleunen M (2010) A multi-species experiment in their native range indicates pre-adaptation of invasive alien plant species. New Phytologist 185: 1087-1099. https://doi.org/10.1111/j.1469-8137.2009.03114.x

Schafer M, Kotanen PM (2003) The influence of soil moisture on losses of buried seeds to fungi. Acta Oecologica 24: 255-263. https://doi.org/10.1016/j.actao.2003.09.001

Schafer M, Kotanen PM (2004) Impacts of naturally-occurring soil fungi on seeds of meadow plants.PlantEcology 175:19-35.https://doi.org/10.1023/B:VEGE.0000048096.00772.23

Simberloff D, Martin JL, Genovesi P, Maris V, Wardle DA, Aronson J, Courchamp F, Galil B, García-Berthou E, Pascal M, Pyšek P (2013) Impacts of biological invasions: what's what and the way forward. Trends in Ecology and Evolution 28: 58-66. https://doi. org/10.1016/j.tree.2012.07.013

Skálová H, Moravcová L, Pyšek P (2011) Germination dynamics and seedling frost resistance of invasive and native Impatiens species reflect local climatic conditions. Perspectives in Plant Ecology, Evolution and Systematics 13: 173-180. https://doi.org/10.1016/j. ppees.2011.03.005

Skálová H, Havlíčková V, Pyšek P (2012) Seedling traits, plasticity and local differentiation as strategies of invasive species of Impatiens in central Europe. Annals of Botany 110: 14291438. https://doi.org/10.1093/aob/mcr316

Skálová H, Jarošík V, Dvořáčková Š, Pyšek P (2013) Effect of intra- and interspecific competition on the performance of native and invasive species of Impatiens under varying levels of shade and moisture. PLOS One 8: e62842. https://doi.org/10.1371/journal. pone.0062842

Slavík B (1997) Impatiens L. In: Slavík B, Chrtek Jr J, Tomšovic P (Eds) Květena České republiky 5. Academia, Praha, 230-240. [Flora of the Czech Republic]

Thompson K, Bekker JP, Bekker RM (1997) The soil seed bank of northwest Europe: methodology, density and longevity. Cambridge University Press, Cambridge.

Tolasz R, Míková T, Valeriánová A, Voženílek V (2007) Climate Atlas of Czechia. Czech Hydrometeorological Institute, Praha/Olomouc.

Thuiller W, Albert C, Araujo MB, Berry PM, Cabeza M, Guisan A, Hickler T, Midgley GF, Paterson J, Schurr FM, Sykes MT, Zimmermann NE (2008) Predicting global change impacts on plant species distributions: future challenges. Perspectives in Plant Ecology, Evolution and Systematics 9: 137-152. https://doi.org/10.1016/j.ppees.2007.09.004 
Van Clef M, Stiles EW (2001) Seed longevity in three pairs of native and non-native congeners: assessing invasive potential. Northeastern Naturalist 8: 301-310. https://doi. org/10.2307/3858486

Van Kleunen M, Weber E, Fischer M (2010) A meta-analysis of trait differences between invasive and non-invasive plant species. Ecology Letters 13: 235-245. https://doi.org/10.1111/ j.1461-0248.2009.01418.x

Vilà M, Espinar JL, Hejda M, Hulme PE, Jarošík V, Maron JL, Pergl J, Schaffner U, Sun Y, Pyšek P (2011) Ecological impacts of invasive alien plants: a meta-analysis of their effects on species, communities and ecosystems. Ecology Letters 14: 702-708. https://doi. org/10.1111/j.1461-0248.2011.01628.x

Wickham H (2016) ggplot2: elegant graphics for data analysis. Springer-Verlag, New York.

Wickham H, François R, Henry L, Müller K (2018) dplyr: a grammar of data manipulation. R package version 0.7.6. https:/CRAN.R-project.org/package=dplyr

Wilsey BJ, Barber K, Martin LM (2015) Exotic grassland species have stronger priority effects than natives regardless of whether they are cultivated or wild genotypes. New Phytologist 205: 928-937. https://doi.org/10.1111/nph.13028

\section{Supplementary material I}

\section{Figure S1. Seed burial in the field}

Authors: Hana Skálová, Lenka Moravcová, Jan Čuda, Petr Pyšek

Data type: multimedia

Copyright notice: This dataset is made available under the Open Database License (http://opendatacommons.org/licenses/odbl/1.0/). The Open Database License $(\mathrm{ODbL})$ is a license agreement intended to allow users to freely share, modify, and use this Dataset while maintaining this same freedom for others, provided that the original source and author(s) are credited.

Link: https://doi.org/10.3897/neobiota.50.34827.suppl1

\section{Supplementary material 2}

Figure S2. Correlation matrix of selected environmental variables on seed germination in March 2009 and seed dormancy in May 2009

Authors: Hana Skálová, Lenka Moravcová, Jan Čuda, Petr Pyšek

Data type: statistical data

Copyright notice: This dataset is made available under the Open Database License (http://opendatacommons.org/licenses/odbl/1.0/). The Open Database License $(\mathrm{ODbL})$ is a license agreement intended to allow users to freely share, modify, and use this Dataset while maintaining this same freedom for others, provided that the original source and author(s) are credited.

Link: https://doi.org/10.3897/neobiota.50.34827.suppl2 


\section{Supplementary material 3}

Figure S3. Daily soil temperatures across the four localities since seed burial in November 2008 until April 2009

Authors: Hana Skálová, Lenka Moravcová, Jan Čuda, Petr Pyšek

Data type: multimedia

Copyright notice: This dataset is made available under the Open Database License (http://opendatacommons.org/licenses/odbl/1.0/). The Open Database License $(\mathrm{ODbL})$ is a license agreement intended to allow users to freely share, modify, and use this Dataset while maintaining this same freedom for others, provided that the original source and author(s) are credited.

Link: https://doi.org/10.3897/neobiota.50.34827.suppl3

\section{Supplementary material 4}

Table S1. Changes in germination and dormancy percentage for three Impatiens species over time

Authors: Hana Skálová, Lenka Moravcová, Jan Čuda, Petr Pyšek

Data type: statistical data

Explanation note: Changes in germination and dormancy percentage (mean \pm standard error) for three Impatiens species (i.e. $\mathrm{G}=I$. glandulifera, $\mathrm{N}=I$. noli-tangere and $\mathrm{P}=I$. parviflora) over time.

Copyright notice: This dataset is made available under the Open Database License (http://opendatacommons.org/licenses/odbl/1.0/). The Open Database License $(\mathrm{ODbL})$ is a license agreement intended to allow users to freely share, modify, and use this Dataset while maintaining this same freedom for others, provided that the original source and author(s) are credited.

Link: https://doi.org/10.3897/neobiota.50.34827.suppl4 